of the injected rats gained full weight, but others remained permanently stunted.

The healthy tolerant animals in the injected litters showed a gain in weight either equal to or greater than the average for the litter-that is, there was no evidence that tolerance was accompanied by any stunting of growth other than that associated with the injection of homologous cells. (In the strain combination used by us $75 \%$ of the injected animals were either non-tolerant or partially tolerant; $10 \%$ were highly tolerant; $15 \%$ jeveloped runt disease.)

\section{Eriects of Cell Dosage}

(1) High Cell Dosage (20-30 Million Cells).-After a slight increase in weight at the end of the first week a steady fall occurred until death ensued within two or three weeks. The majority of animals in this group succumbed early in this manner if they survived the first few days. This group showed a high incidence of early deaths during the first week.

(2) Medium Cell Dosage (10-20 Million Cells).Fewer animals developed runt disease, and those which did tended to lose weight over a longer period. The number of early deaths was considerably less than in the group receiving high cell dosage.

(3) Low Cell Dosage (Below 10 Million Cells).-The incidence of early deaths was virtually eliminated. There was no overt runting, and the only abnormality was retarded gain in weight of the pattern illustrated in Fig. 6.

It is therefore evident from this series that, though reduction in the dosage of cells eliminates runting, a systemic effect is still apparent, as revealed by the weight-gain assay.

(To be concluded, with full list of references, in our next issue)

The Family Allowances and National Insurance Bill has received Royal Assent and a number of changes in the Act have come into operation. For instance, children incapable of regular employment because of long-term disability can now be counted for family allowances and national insurance purposes up to the age of 16 , whether or not they have been able to go to school. Previously this extension only applied to children who had never been able to go to school or who had had to leave before schoolleaving age. Certain additional risks are now covered under the Industrial Injuries Scheme. An accident, occurring in the course of employment, which results from another person's misconduct, "skylarking" or negligence, or is caused by an animal, or results from the injured person being struck by an object or by lightning can be regarded as an industrial accident, provided the injured person did not contribute to the happening of the accident by any conduct or action unconnected with his employment. The Special Hardship Allowance under the Industrial Injuries Scheme is to compensate people who as a result of industrial injury or disease are unable to follow their regular occupations or employment of a similar standard. The Act extends "regular occupation" for this allowance to include employment to which people in an occupation normally advance and of which a claimant, had he not been injured, would have had at least the normal prospect. A man will now be treated as incapable of following his regular òccupation so long as he is deprived of these prospects because of the effects of an industrial accident or disease.

\section{ACUTE GASTRO-INTESTINAL ILLNESS IN GENERAL PRACTICE}

BY

E. TUCKMAN,* M.B., D.C.H., D.T.M.\&H.

P. A. L. CHAPPLE, M.B.

L. M. FRANKLIN, M.R.C.S., D.P.H.

I. N. MANSER, M.R.C.S.

J. T. WOODALL, M.B., D.Obst.R.C.O.G.

General Practitioners, St. Paul's Cray, Kent

K. J. RANDALL, M.D.

Department of Pathology, Orpington Hospital

AND

J. C. McDONALD, M.D., D.P.H.

Epidemiological Research Laboratory, Colindale, London

Although about $5 \%$ of patients who consult family doctors in this country have symptoms of acute gastrointestinal infections (Logan and Cushion, 1958), little information is available on the clinical and epidemiological features of these illnesses, and there are no reports of therapeutic trials in their management outside hospital. We present here a report of an investigation carried out in a group general practice, the patients of which are mainly those living on a London County Council housing estate in the north-west corner of Kent ; the age-and-sex structure of the population is shown in Table I. The major part of the study was carried out during the two years 1957 and 1958, but certain aspects of it continued until the end of August, 1959. Five general practitioners took part during the first year

TABle I.-Age and Sex of Population Studied

\begin{tabular}{c|c|c|c|r|r|r}
\hline \multirow{2}{*}{$\begin{array}{c}\text { Age } \\
\text { (Years) }\end{array}$} & \multicolumn{3}{|c|}{1957} & \multicolumn{3}{|c}{1958} \\
\cline { 2 - 7 } & Malo & Female & Total & Male & Fomale & Total \\
\hline $0-4$ & 380 & 379 & 759 & 314 & 326 & 640 \\
$5-14$ & 1,026 & 1,051 & 2,077 & 756 & 710 & 1,466 \\
$15-39$ & 1,602 & 1,599 & 3,201 & 1,116 & 1,290 & 2,406 \\
$40+$ & 1,028 & 976 & 2,004 & 821 & 791 & 1,612 \\
\hline All ages & 4,036 & 4,005 & 8,041 & 3,007 & 3,117 & 6,124 \\
\hline
\end{tabular}

and four thereafter. The objects of the study were to investigate the clinical features, bacteriology, and epidemiology of acute gastro-intestinal disease in the home and to evaluate neomycin and phthalylsulphathiazole in treatment.

\section{Clinical Methods \\ Main Survey}

Every patient seen either in the home or in the consulting-room who was thought to be suffering from an acute infection of the gastro-intestinal tract or from food-poisoning was included unless, when first seen, symptoms had been present for more than seven days or antibiotics were being taken at the time of onset of the symptoms. Information about each case was recorded in a standard manner on specially printed cards, the main symptoms, the symptom that appeared first, and the symptom that was most troublesome being noted. The consumption of certain foods (cream cakes, sausages, canned meat, and reheated meat) during the 48 hours before onset, regular eating in a canteen at work or at school, contact with a similar case during the week

*Walter Dixon Memorial Research Scholar (B.M.A.), 1957-9. 
before onset, and the presence of pets in the house were also recorded. The age and occupation of all members of the household, together with the date of any gastro-intestinal illness which had begun not more than 14 days before the attendance of the primary case, were included in the record. A household was defined as all those who fed from the same kitchen.

The patient, or the patient's parent, was asked to post a stool specimen to the laboratory at Orpington Hospital as soon as possible after the patient had been seen by the doctor, and $84 \%$ of them did this. If the patient was to be admitted to hospital the doctor was asked to take a rectal swab before the patient left home-but this was done in only half the cases. Each patient was seen or revisited two and seven days after the first attendance or as near to these times as possible. On each occasion the doctor recorded his impression of whether the patient had recovered and also the patient's (or the parent's) opinion. In addition, the doctor noted whether or not the patient was in bed, was vomiting, or had loose stools, and whether any other member of the household had developed symptoms of gastrointestinal infection, with the date of onset of any such symptoms.

\section{Subsidiary Studies}

During the first 12 months of the investigation over one-quarter of specimens from children under 5 years of age yielded Proteus, and a study was therefore undertaken to determine the incidence of this organism in the stools of normal children of the same age. Between December, 1957, and August, 1959, stools from 78 healthy children under 5 years of age were sent for this purpose to the laboratory, the accompanying request form giving no indication to the pathologist of whether the specimen was from a case or a control.

In view of the absence of many cases of any demonstrable bacteriological cause for the illness during the first year and a half of the survey, a subsidiary study using virological methods was begun in September, 1958, and continued for 12 months. During this period faecal specimens from 49 patients under 5 years of age were tested for the presence of E.C.H.O. virus in addition to the routine bacteriological examination. An attempt was made to match each of these with a control specimen from a healthy child whose age did not differ by more than three months from the sick child's and whose family was of a similar size. This was, however, achieved in only 29 cases.

\section{Therapentic Trial}

Five doctors participated in this trial, which began in July, 1957, and lasted until July, 1959. Patients aged more than 2 years were included if the doctor thought they were suffering from dysentery and if he would normally have considered treating them with chemotherapy. The nature of the trial was explained to the patient or to his parents and consent was obtained before the patient was included. Patients were treated, in accordance with a random series, with kaolin and neomycin, kaolin and phthalylsulphathiazole, or kaolin

TABLE II.-Daily Dose of Medicaments

\begin{tabular}{c|c|c|c}
\hline Age (Years) & Neomycin (g.) & $\begin{array}{c}\text { Phthalyl- } \\
\text { sulphathiazole } \\
\text { (g.) }\end{array}$ & Kaolin (g.) \\
\hline $2-4$ & 1 & 1 & $2 \cdot 8$ \\
$5-9$ & 2 & 2 & 5.6 \\
$10+$ & 3 & 3 & 8.4 \\
\hline
\end{tabular}

alone; the drugs were given four times daily for five days. The daily dosage of each of these medicaments is shown in Table II.

The three preparations were as nearly as possible alike in appearance, and the doctor did not know what treatment any particular patient was receiving. He could, however, at any time consult one of us (K. J.R.), who held the key, if he felt that it was in the patient's interests to know what treatment was being given.

\section{Laboratory Methods}

At the laboratory wet preparations were made and examined for the presence of blood, pus, amoebae, cysts, or parasites. The specimens were plated on (1) deoxycholate citrate agar; (2) Wilson and Blair's bismuth sulphite agar; (3) selenite $F$ enrichment medium ; and, for children under 5, (4) MacConkey's agar. Subcultures were made from (3) on to (1) and (2) after 24 hours. Non-lactose-fermenting organisms identified from the solid selective media were investigated by standard biochemical methods with, in addition, the inoculation of a triple sugar-iron agar slope.

Strains of Proteus were identified by their sugar reactions and by their ability to split urea using Christensen's medium. Strains of Salmonella and Shigella were identified biochemically and typed serologically, and the typing of salmonella organisms was confirmed by the Salmonella Reference Laboratory at Colindale. Lactose fermenters isolated on MacConkey's agar from children under 5 years were tested for the presence of pathogenic Escherichia coli strains using specific antisera.

All cultures were examined at 24 hours, 48 hours, and 7 days before being discarded. It was originally intended that the specimens should be examined for heat-resistant strains of Clostridium welchii, but this was not found practicable.

Virological Methods.-When specimens from young children were to be examined for the presence of E.C.H.O. viruses, the mother was asked to put some of the faeces in a screw-capped glass container and take it immediately to the doctor. On arrival the specimen was at once placed on solid carbon dioxide and held frozen in this way until delivered to the Virus Diagnostic Laboratory at Colindale. Each specimen was there tested by inoculation into two monkey-kidney-tissue culture tubes maintained in medium 199. After incubation for seven days the supernatant fluid from the two tubes was pooled and used to inoculate two more monkey-kidney tubes and the original pair of tubes were replenished with fresh medium 199. All four tubes were then incubated for a further seven days.

\section{Results}

Incidence of Gastro-intestinal Illness and Bacteriological Findings

During the two years 1957-8 there were 738 illnesses -an incidence per annum in the population at risk of $5.2 \%$. Stool specimens from $622(84 \%)$ of the patients were examined at the laboratory and the bacteriological findings are shown in Table III. The age incidence is given in Table IV, the incidence of illnesses due to Sh. sonnei and all other illnesses being shown separately. Fig. 1 shows the seasonal incidence of illness during the two years according to age-group.

Except during the first half of 1957, when Sonne dysentery was prevalent, there was a striking absence 
of bacterial pathogens. The excess incidence in the pre-school and school children during the first six months of 1957 was due wholly to the epidemic of Sonne dysentery, which was confined almost entirely to these age-groups. Sh. sonnei was isolated on only four occasions during the last 18 months of the survey. During the last quarter of the second year the incidence of sickness in the two younger age-groups rose again, but this was not due to $S h$. sonnei, and the cause was not found. In those over school age there was little seasonal variation during the whole two years and the total incidence was consistently below that of the younger age-groups.

No difference in the incidence of illness in the two sexes was noted in pre-school children or in adults aged 40 or more. There was a slight male excess among school children, and a definite excess of females among those aged 15-39 years.

Proteus Study.-Up to December, 1957, bacteriological examination of the stools of 127 children under 5 years of age had been performed and $36(28 \%)$ of these had yielded Proteus. From December, 1957, to

TABLE III.-Bacteriological Findings by Quarters in 1957 and 1958

\begin{tabular}{|c|c|c|c|c|c|c|c|c|c|}
\hline & \multicolumn{4}{|c|}{1957} & \multicolumn{4}{|c|}{1958} & \multirow{2}{*}{ Total } \\
\hline & 1st & 2nd & 3rd & 4th & 1st & 2nd & 3rd & 4th & \\
\hline 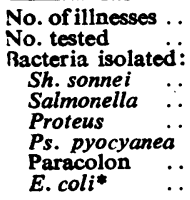 & $\begin{array}{r}187 \\
153 \\
74 \\
0 \\
0 \\
15 \\
1 \\
0 \\
0\end{array}$ & $\begin{array}{r}136 \\
121 \\
37 \\
0 \\
19 \\
0 \\
1 \\
6\end{array}$ & $\begin{array}{r}75 \\
66 \\
2 \\
2 \\
1 \\
12 \\
0 \\
2 \\
1\end{array}$ & $\begin{array}{r}66 \\
56 \\
1 \\
0 \\
18 \\
0 \\
2 \\
0\end{array}$ & $\begin{array}{r}71 \\
61 \\
0 \\
0 \\
15 \\
0 \\
0 \\
0\end{array}$ & $\begin{array}{r}60 \\
53 \\
0 \\
0 \\
15 \\
0 \\
0 \\
0\end{array}$ & $\begin{array}{r}50 \\
40 \\
1 \\
1 \\
2 \\
12 \\
0 \\
2 \\
0\end{array}$ & $\begin{array}{r}93 \\
72 \\
0 \\
0 \\
13 \\
5 \\
6 \\
0\end{array}$ & $\begin{array}{l}738 \\
622 \\
115(18 \%) \\
3(0 \cdot 5 \%) \\
119(19 \%) \\
6(1 \%) \\
13(2 \%) \\
7(3 \%)\end{array}$ \\
\hline
\end{tabular}

TABLE IV.-Incidence (\%) of Sonne Dysentery and Other Illnesses in Age-groups

\begin{tabular}{|c|c|c|c|c|c|c|}
\hline \multirow{2}{*}{$\begin{array}{c}\text { Age } \\
\text { (Years) }\end{array}$} & \multicolumn{3}{|c|}{1957} & \multicolumn{3}{|c|}{1958} \\
\hline & $\begin{array}{c}\text { All } \\
\text { Illness }\end{array}$ & Sonne & $\begin{array}{l}\text { Non- } \\
\text { Sonne }\end{array}$ & $\begin{array}{c}\text { All } \\
\text { Illness }\end{array}$ & Sonne & $\begin{array}{l}\text { Non- } \\
\text { Sonne }\end{array}$ \\
\hline $\begin{array}{c}0-4 \\
5-14 \\
15-39 \\
40+\end{array}$ & $\begin{array}{r}19 \cdot 1 \\
8 \cdot 5 \\
3 \cdot 0 \\
2 \cdot 3\end{array}$ & $\begin{array}{l}2.8 \\
3.4 \\
0.6 \\
0.1\end{array}$ & $\begin{array}{r}16 \cdot 3 \\
5 \cdot 1 \\
2 \cdot 4 \\
2 \cdot 2\end{array}$ & $\begin{array}{r}14.2 \\
5.3 \\
3.0 \\
1.9\end{array}$ & $\begin{array}{l}0 \cdot 2 \\
0 \\
0 \\
0\end{array}$ & $\begin{array}{r}14.0 \\
5.3 \\
3.0 \\
1.9\end{array}$ \\
\hline All ages & 5.8 & 1.4 & $4 \cdot 4$ & $4 \cdot 5$ & 0 & 4.5 \\
\hline
\end{tabular}

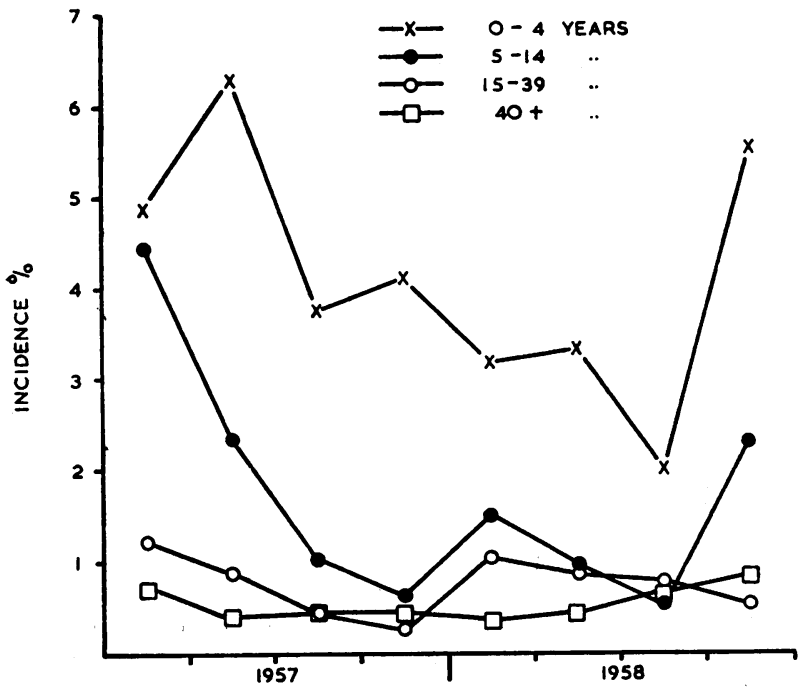

FIG. 1.-Quarterly incidence (\%) of gastro-intestinal illness in age-groups. $1957-8$.
August, 1959, stools from a further 108 sick children were examined together with specimens from healthy controls. The results are set out in Table V. Except for a small difference with Pr. vulgaris, the stools of normal children yielded Proteus as often as those from

TABle V.-Proteus in Patients and Healthy Children Under 5 Years of Age

\begin{tabular}{|c|c|c|c|}
\hline & $\begin{array}{c}\text { Cases in } \\
\text { Pre-control Period }\end{array}$ & $\begin{array}{c}\text { Cases in } \\
\text { Control Period }\end{array}$ & $\begin{array}{l}\text { Healthy } \\
\text { Controls }\end{array}$ \\
\hline $\begin{array}{ll}\begin{array}{l}\text { Pr. morgani } \\
\text { Pr. vulgaris }\end{array} & \ldots \\
\text { Pr. mirabilis } & \ldots \\
\end{array}$ & $\begin{array}{c}23(18 \%) \\
5(4 \%) \\
8(6 \%)\end{array}$ & $\begin{array}{l}25(23 \%) \\
8(7 \%) \\
0\end{array}$ & $\begin{array}{l}17 *(22 \%) \\
3 *(4 \%) \\
0\end{array}$ \\
\hline Total Proteus & $36(28 \%)$ & $33(31 \%)$ & $19 *(24 \%)$ \\
\hline Total tested & 127 & 108 & 78 \\
\hline
\end{tabular}

* Both Pr. morgani and Pr. vulgaris were isolated from one patient.

children with gastro-intestinal symptoms and there was thus no evidence that this organism played any part in the aetiology of the illnesses. The incidence of paracolon organisms (5\%) and of Ps. pyocyanea infection ( $1 \%$ ) was also the same in both groups.

Virological Study.-E.C.H.O. virus type 4 was isolated from one case of gastro-intestinal illness and from none of the controls. The patient from whom this strain was isolated was a female aged 18 months with diarrhoea and vomiting lasting for five days in November, 1958 : a brother aged 5 had had diarrhoea three days earlier, and a sister aged 9 developed diarrhoea three days later.

\section{Clinical Analysis}

The clinical features of patients from whom Sh. sonnei was isolated were compared with those from whom it was not, and some of the results are set out in Table VI for the three age-groups $0-4,5-14$, and 15 years or more.

Table VI.-Clinical Features in Patients Tested Bacteriologically

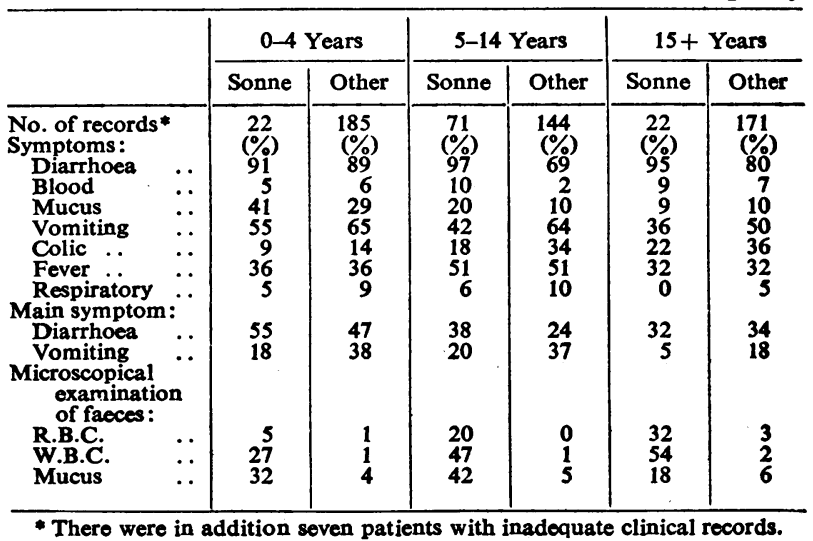

No difference in the acuteness of onset of illness was detected between the two groups, but, as can be seen from the Table, diarrhoea was much commoner in the Sonne group, only $4 \%$ having no diarrhoea, compared with $20 \%$ of the non-Sonne group. Furthermore, the duration of the diarrhoea was longer in the Sonne group, $55 \%$ having diarrhoea for more than three days as compared with $24 \%$ of the non-Sonne group. In the latter group vomiting was more often the main complaint and abdominal colic and respiratory symptoms were more frequent, but in spite of any differences no clear-cut. differentiation in the clinical picture shown by the two groups could be made. By far the best method short. of bacteriological examination was the microscopical examination of faeces. Red and white cells and mucus 
were seldom present in the absence of $S h$. sonnei. Nevertheless they were found in the stools of less than half the patients with Sonne dysentery.

Although most of the illnesses were very mild, Sonne dysentery tended to be more severe and caused patients to spend longer in bed: $70 \%$ of the non-Sonne group did not go to bed at all, compared with $56 \%$ of the Sonne group, while only $7 \%$ of the non-Sonne group spent more than three days in bed compared with $12 \%$ of the Sonne group.

Relapses, defined as any recurrence of symptoms within 28 days of the onset of illness, occurred in $4 \%$ of the Sonne cases and in $4 \%$ of the non-Sonne cases. All the relapses occurred among the 480 patients who had diarrhoea in the original illness. There were no relapses in patients who had other symptoms but not diarrhoea.

\section{Hospital Admissions}

Of the 738 patients, 54 (7\%) were admitted to hospital, and 19 of these had neither faeces nor rectal swabs examined. Forty-one of the patients were admitted with a diagnosis of appendicitis and all but four underwent appendicectomy ; laboratory examination of faecal specimens was made in 23 cases, in two of which Sh. sonnei was isolated. Ten patients were admitted with dysentery ; specimens from all were examined and Sh. sonnei was isolated from five of them. One patient was admitted with intestinal obstruction, one with gastroenteritis, and in a third no diagnosis was made either by the family doctor or at the hospital.

\section{Sources of Infection}

Foods.-An analysis was made by age-groups of foods taken in the 48 hours before the onset of symptoms. This showed that $10 \%$ of all patients had eaten cream cakes, $17 \%$ sausages, $8 \%$ canned meat, and $8 \%$ reheated meat. The illnesses were divided into Sonne and nonSonne groups, and when age was allowed for no difference was found between the two groups with regard to foods taken, except that sausages had been eaten one and a half times more often in the non-Sonne group ; the excess was greatest in those who had suffered from vomiting. The bacteriologically negative group was divided into three clinical categories-those with diarrhoea but no vomiting, those with vomiting but no diarrhoea, and those with both vomiting and diarrhoea. In this group of cases we found no excess in the consumption of any of the foods in any of the three clinical categories.

Pets.-A similar analysis was made with regard to household pets. Dogs were present in about one-fifth of the homes, cats in a similar proportion, and birds in about two-fifths. We found no difference between the Sonne and non-Sonne groups and no evidence of an association between the presence of pets and the type of illness.

Contact with Other Illness.-A history of contact with a gastro-intestinal illness in the previous 14 days was given in $35 \%$ of the patients infected with Sh. sonnei and in $25 \%$ of those not so infected. In the non-Sonne group of cases $36 \%$ of those who had vomited gave a history of contact with a similar illness.

Canteens.-No difference in the history of canteen feeding was found between the Sonne and non-Sonne groups when age was allowed for.

\section{Influence of Schoolchildren}

Fig. 2 shows the monthly incidence of Sonne dysentery in children aged 5-14 years: the incidence for three separate primary schools is also shown, and it will be seen that the epidemic reached a peak at different dates at different schools. School $G$ is situated between the other two schools and it seems probable that the spread of the epidemic took place both geographically and in time from school to school.

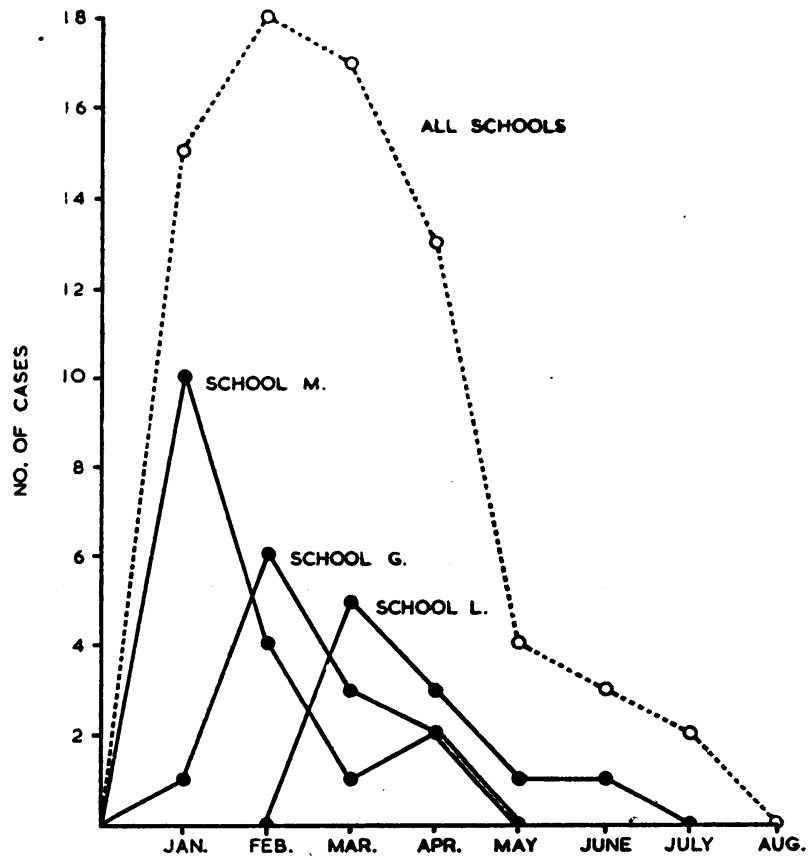

Fig. 2.-Month of onset of Sonne dysentery among children aged 5-14 years by school. 1957 .

The incidence of Sonne dysentery in families with and without schoolchildren was studied. There were 36 cases in families with children at school and seven cases in families without children of school age. In only one doctor's practice (J. T. W.) was it possible to relate those attacked in each age-group to the number at risk, and Table VII gives the attack rate for this practice and the age distribution of those attacked in the other practices. The evidence shown in this Table strongly suggested that the source of Sonne infection in the

TABle VII.-Sonne Dysentery in Families With and Without Schoolchildren

\begin{tabular}{|c|c|c|c|c|c|c|c|c|}
\hline \multirow{3}{*}{$\begin{array}{c}\text { Age } \\
\text { (Years) }\end{array}$} & \multicolumn{4}{|c|}{ J. T. W.'s Practice } & \multicolumn{4}{|c|}{ Other Practices } \\
\hline & \multicolumn{2}{|c|}{ With } & \multicolumn{2}{|c|}{ Without } & \multicolumn{2}{|c|}{ With } & \multicolumn{2}{|c|}{ Without } \\
\hline & No. & Cases & No. & Cases & No. & Cases & No. & Cases \\
\hline $\begin{array}{c}0-4 \\
15-39 \\
40+\end{array}$ & $\begin{array}{l}104 \\
357 \\
194\end{array}$ & $\begin{array}{l}5 \\
7 \\
0\end{array}$ & $\begin{array}{l}103 \\
318 \\
290\end{array}$ & $\begin{array}{l}1 \\
0 \\
0\end{array}$ & & $\begin{array}{r}12 \\
11 \\
1\end{array}$ & & $\begin{array}{l}3 \\
1 \\
2\end{array}$ \\
\hline Total & 655 & 12 & 711 & 1 & $\underset{\text { known }}{\text { Not }}$ & 24 & $\underset{\text { known }}{\text { Not }}$ & 6 \\
\hline
\end{tabular}

community was primarily the schookhildren. It was evidently they who introduced the infection into the family and caused further spread.

A similar study was made of the families with a nonSonne illness, and this showed no clear association between the presence of schoolchildren and the incidence of the illness. In these illnesses the ratio of families with schoolchildren to families without schoolchildren was only 1.5 to 1 , whereas the corresponding ratio in the Sonne group was 5 to 1 . 


\section{Behaviour in Families}

Sh. sonnei was isolated from the stools of at least one member of 96 families. In 61 of these families no further case of gastro-intestinal illness occurred within a period of one month, but in 35 families secondary cases did appear. The age distribution of the first case in the family with both Sonne and non-Sonne illness is shown in Table VIII and the secondary attack rates in Table IX.

TABLE VIII.-Age Distribution of First Case in Family

\begin{tabular}{|c|c|c|}
\hline Age (Years) & Sonne & Non-Sonne \\
\hline $\begin{array}{l}0-4 \\
5-14 \\
15+\end{array}$ & $\begin{array}{l}18(18 \%) \\
66(65 \%) \\
17(17 \%)\end{array}$ & $\begin{array}{l}195(34 \%) \\
167(29 \%) \\
210(37 \%)\end{array}$ \\
\hline Total & $101(100 \%)$ & $572(100 \%)$ \\
\hline
\end{tabular}

TABlB IX.-Secondary Attack Rates in Families

\begin{tabular}{c|c|c|c|c|c|c}
\hline \multirow{2}{*}{\begin{tabular}{c|c|c|c|c} 
Age \\
Years)
\end{tabular}} & \multicolumn{3}{|c|}{ Sonne Dysontery } & \multicolumn{3}{c|}{ Non-Sonne Illness } \\
\cline { 2 - 6 } & $\begin{array}{c}\text { No. } \\
\text { Expesed }\end{array}$ & $\begin{array}{c}\text { No. } \\
\text { Attacked }\end{array}$ & $\begin{array}{c}\text { Attack } \\
\text { Rate }\end{array}$ & $\begin{array}{c}\text { No. } \\
\text { Exposed }\end{array}$ & $\begin{array}{c}\text { No. } \\
\text { Attacked }\end{array}$ & $\begin{array}{c}\text { Attack } \\
\text { Rate }\end{array}$ \\
\hline $0-4$ & 40 & 12 & $30 \%$ & 245 & 41 & $17 \%$ \\
$5-14$ & 120 & 24 & $20 \%$ & 576 & 87 & $15 \%$ \\
$15+$ & 208 & 21 & $10 \%$ & 1,157 & 107 & $9 \%$ \\
\hline Total & 368 & 57 & $15 \%$ & 1,978 & 235 & $12 \%$ \\
\hline
\end{tabular}

As can be seen from Table VIII, first cases in the nonSonne group were distributed evenly through the agegroups, whereas with Sonne dysentery there was a considerable excess in the children of school age. On the other hand, the secondary attack rates in each type of illness were highest in the pre-school children and in both groups they fell with advancing age. For all age-groups, rates were rather higher in the Sonne than in the non-Sonne illnesses, but there were no appreciable sex differences. Secondary attack rates by age in non-Sonne illnesses were also studied in relation to the main clinical features of the primary case, and it was found that the group with vomiting and no diarrhoea had higher rates than those with diarrhoea and no vomiting, especially in children aged 5-14.

Serial Intervals. - The distribution of time intervals between the onset of the first and all subsequent cases in family outbreaks was analysed in three types of outbreak: (1) those in which Sh. sonnei was isolated from at least one of the patients; (2) those in which Sh. sonnei was not isolated and the primary case had diarrhoea ; and (3) those in which Sh. sonnei was not isolated and the primary case had vomiting but no diarrhoea. The results of the analysis are shown in Fig. 3, where it may be seen that each of the three curves is different from the others. In Sonne dysentery the most frequent intervals were three to five days; in the bacteriologically negative outbreaks intervals of one to three days were commoner.

\section{Therapeutic Trial}

The therapeutic trial was unfortunately not begun until July, 1957, by which time the epidemic of Sonne dysentery had ended. As a result suitable patients were difficult to find and only 94 were treated. Stool specimens from 85 were tested at the laboratory and pathogenic organisms were isolated from only twoSh. sonnei from one and Salm. typhi-murium from the other.
In the remaining 83 bacteriologically negative cases, eight patients did not take the medicaments in adequate amounts. In eight cases the treatment was changed by the doctor because he was dissatisfied with the patient's progress ; three of these were being treated with kaolin alone, four with neomycin, and one with phthalylsulphathiazole. There was little difference between the three treatment groups in the average duration of the illness, which was about 48 hours, or in the average time spent in bed-less than one day. On the other hand, $42 \%$ of the patients receiving kaolin alone felt ill for three days or more compared with $17 \%$ of the patients who had taken either neomycin or phthalylsulphathiazole in addition to the kaolin. Although the difference is statistically significant (D./S.E. $=25 / 11=$ 2.3) we doubt whether any conclusion should be drawn from this, as the difference did not apply to all the age-groups and the drugs did not reduce the number of patients who had diarrhoea lasting three days or more. Further study of the value of such drugs in the treatment of these illnesses is needed.

\section{Discussion}

In this survey every case of acute gastro-intestinal illness brought to a doctor during the course of two years, in a population of known age-and-sex structure, was recorded and $84 \%$ of the illnesses were studied bacteriologically. But even two years is not long enough to put into perspective epidemics such as that of Sonne dysentery in 1957 or the very low incidence of salmonellosis. We did not test for food-poisoning due to the toxins of staphylococci or $\mathrm{Cl}$. welchii, but to some extent
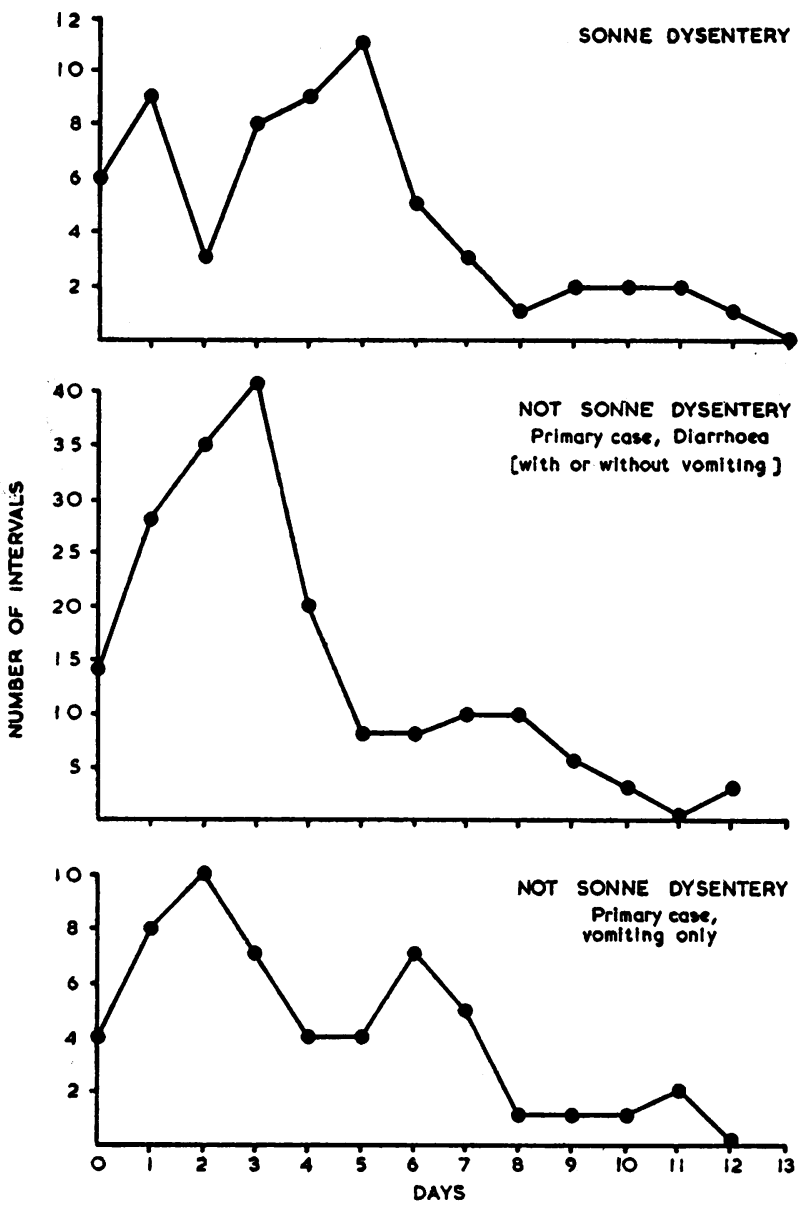

Fio. 3.-Serial intervals. 
this deficiency can be lessened by considering the clinical findings in the 497 patients from whom neither $S h$. sonnei, nor $E$. coli, nor salmonella were isolated. Using only three characteristics-diarrhoea, vomiting, and fever-the 490 for whom there were satisfactory clinical records could be divided into eight groups distributed as follows:

Diarrhoea but no vomiting ..

Vomiting but no diarrhoea.

Diarrhoea and vomiting

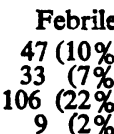

Not febrile

$47(10 \%)$

$33(7 \%)$

9 (2\%)

.. $\quad 121(25 \%)$

$114(23 \%)$
.. $\quad 27(6 \%)$

Almost all patients with $\mathrm{Cl}$. welchii food-poisoning have diarrhoea ; very few have vomiting or fever (Hobbs et al., 1953 ; Beck et al., 1954). Even if all the afebrile diarrhoeas were due to this cause, which is most unlikely, the proportion would be only $25 \%$ of the non-Sonne illnesses. Staphylococcal food-poisoning is characterized by vomiting, seldom with fever, but often with some diarrhoea (Allison et al., 1949). In this survey afebrile patients with vomiting only or diarrhoea and vomiting logether comprised $30 \%$. Once again it seems improbable that all these could be attributed to this cause, especially as any patients with epidemic or winter vomiting disease would come into this group. Probably, therefore, at least half the bacteriologically negative illnesses could not be ascribed to either staphylococcal or $\mathrm{Cl}$. welchii poisoning. These illnesses, consisting for the most part of febrile gastro-enteritis, were not only clinically indistinguishable from Sonne dysentery but were also more common than Sonne dysentery even during the time when a Sonne epidemic was occurring. Further support for the conclusion that most of the bacteriologically negative cases were not due to foodpoisoning was obtained from analysis of the doctor's diagnoses recorded before the bacteriological report was known ; $89 \%$ of the Sonne infections were diagnosed as dysentery and $62 \%$ of the negative group, the difference between these proportions being least in the age-group 0-4 years.

The aetiology of these dysentery-like illnesses remains unknown. Some may possibly be caused by enteroviruses (Ramos-Alvarez and Sabin, 1958 ; Sommerville, 1958), but in the year of our small virus study E.C.H.O. virus was isolated in only 1 of 49 illnesses. The role of coliform bacteria, reviewed by Taylor (1955), is also uncertain, but with the doubtful exception of Pr. vulgaris we found Proteus, Ps. pyocyanea, or paracolon organisms no more frequently in the sick than in the healthy. If any of these or other common alimentary bacteria are pathogenic it seems unlikely that they will be identified epidemiologically unless they can be subdivided by serological or biochemical means.

The value of this survey would of course be increased if there was reason to believe that the findings could be applied to other years and to other parts of the country. So far as Sonne dysentery, salmonellosis, enterovirus infection, and probably any other individual cause is concerned, large fluctuations in their epidemicity make this clearly impossible, but our figures for total incidence probably have a more general application. Thus the incidence of sickness in $1957(5.8 \%)$ and in $1958(4.5 \%)$ agrees quite well with the results of the study in 106 practices in England and Wales in 1955-6 carried out jointly by the College of General Practitioners and the General Register Office (Logan and Cushion, 1958). In this study the incidence figures for dysentery $(0.2 \%)$, food-poisoning $(0.1 \%)$, gastritis and duodenitis $(1.4 \%)$, appendicitis $(0.4 \%)$, and gastro-enteritis $(2.2 \%)$ together add up to $4.3 \%$. The age-specific incidence figures in their survey and in ours were very similar, but the proportion of the population studied in our survey aged less than 15 years was $35 \%$ compared with $22 \%$ in the larger one, and this could account for our total incidence figure being rather higher.

Further evidence for believing that our findings ma! be applied more generally was obtained from the unpublished results of a survey carried out by one of us (J. C. McD.) for 12 months in two London boroughs in 1953-4. The population studied consisted of 9,972 persons in 2,273 families selected because a child in each family was already under observation in a trial of pertussis vaccine. There was thus an even highe? proportion of children (41\%) than in St. Paul's Cray. The total attack rate of acute gastro-intestinal illnes: in this survey was $18.6 \%$, but only $35 \%$ of the illnesses were seen by a doctor, so the comparable incidence figure was $6.5 \%$. The age-specific rates and distribution of illness in clinical categories in the 1953-4 survey were also very similar to those in the current one. It seems reasonable to conclude therefore that about $5 \%$ of the population each year have an acute gastro-intestinal illness for which they seek medical advice but that perhaps twice as many others have illnesses which they do not report.

\section{Summary}

A clinical, bacteriological, and epidemiological survey of acute gastro-intestinal illness was made in a general practice comprising over 8,000 patients in the outskirts of South East London. The main study lasted two years -1957-8-but certain aspects were continued unti] September, 1959.

The incidence of sickness seen by a doctor was $5.8 \%$ in 1957 and $4.5 \%$ in 1958, the difference being entirely due to an epidemic of Sonne dysentery in the first year. Age, sex, and seasonal variations are described. Of the patients seen, $7 \%$ were admitted to hospital, most of them diagnosed as cases of appendicitis.

Specimens from over four-fifths of the 738 illnesse: studied were tested bacteriologically. Sh. sonnei wa: isolated from $18 \%(29 \%$ in 1957 and $0.4 \%$ in 1958), Salmonella from $0.5 \%$, and serologically identifiable $E$. coli were isolated from $3 \%$ of children under 2 years of age. No bacterial pathogens were found in the great majority.

The incidence of Proteus, paracolon organisms, and $P s$. pyocyanea was the same in cases and healthy controls under 5 yeats of age.

Faeces from 49 cases and 29 healthy children aged less than 5 years were tested for the presence of E.C.H.O viruses; a strain of type 4 virus was isolated from one patient but not from any controls.

The frequency of the main signs and symptoms showed only minor differences between Sonne dysentery and the other illnesses. Apart from bacteriology the best distinction was by microscopy of faeces ; red cells, white cells, and mucus were virtually confined to the Sonne group.

Clinical evidence suggested that not more than half the bacteriologically negative illnesses were attributable to staphylococcal or $\mathrm{Cl}$. welchii toxin food-poisoning. About a third of all patients had a febrile dysenteric illness of undetermined cause.

Patients divided into clinical and bacteriological groups were studied in relation to certain foods taken 
before onset, canteen meals, household pets, contact with other similar illness, and presence of schoolchildren in the family. The only factor that stood out clearly was the importance of schools and schoolchildren in Sonne dysentery. Age-specific secondary attack rates and serial intervals between cases in families showed differences in the bacteriological and clinical groups.

In a therapeutic trial of neomycin and phthalylsulphathiazole in 83 patients, all bacteriologically negative, little difference in rate of recovery was found between those treated with either drug and kaolin and those treated with kaolin alone.

We are indebted to Glaxo Laboratories for supplying the preparations used in the therapeutic trial; to Dr. C. E. D. Taylor, of the Virus Diagnostic Laboratory at Colindale, for the virus isolation tests; to Dr. Z. Bencic for his heip in the analysis of the records; to Mr. F. T. M. Downing for technical assistance; and to the South-east Metropolitan Regional Hospital Board for a grant in respect of the bacteriological part of the investigation.

\section{RBFERENCES}

Allison, V. D., Hobbs, B. C., and Martin, P. H. (1949). Montids Bull. Minist. Hlth Lab." Serv., 8, 38.

Beck, A., Foxeli, A. W. H., and Turner, W. C. (1954). Brt: med. J., 1, 686 .

Hobbs, B. C.., Smith, M. E., Oakley, C. L., Warrack, G. H.s and Cruickshank, J. C. (1953). J. Hyg. (Lond.), 51, 75.

Logan, W. P. D., and Cushion, A. A. (1958). Studies on Medica and Population Subjects, No. 14. H.M.S.O., London.

Ramos-Alvarez, M., and Sabin, A. B. (1958). J. Amer. med. Ass.. $167,147$.

Sommerville, R. G. (1958). Lancet, $2,1347$.
Taylor, J. (19.55). d. appl. Bact., 18, 596.

\title{
PROSTATECTOMY MORTALITY
}

\section{a Changing picture}

\section{BY
C. G. SCORER, M.D., F.R.C.S. Surgeon \\ AND \\ SHIRLEY J. KNIGHT, M.B., D.Obst.R.C.O.G. Lately House-Surgeon}

\author{
Hillingdon Hospital, Uxbridge, Middlesex
}

The mortality of prostatectomy has fallen in recent years. Early in this century a figure of about $20 \%$ was published from large hospitals (Groves, 1908 ; Dobson, 1921 ; Wade, 1921; Thomson-Walker, 1930). The decline in death rate evidently started about two decades ago, for Rees (1947) gives a figure of $8.4 \%$ (463 cases) at Birmingham for the seven-year period from 1939 , and Salvaris (1960) records a mortality of $4.2 \%(1,200$ cases) from the urological hospitals in London.

In individual series, however, where careful selection probably occurs, results have always been better, and even at an early period mortality was $5 \%$ or less (Tenney and Chase, 1906 ; Freyer, 1912). One surgeon's choice of patients for operation differs from another's and, indeed, a single surgeon's choice may alter considerably in the course of years. For this reason comparison of published mortality figures for an operation like prostatectomy may be fallacious. By careful selection of cases for operation a very low mortality can undoubtedly be achieved, but this merely raises significant questions. What happens to those who have not been considered for surgery? Do they languish with a permanent suprapubic cystostomy? Do they succumb to infection or renal insufficiency? How many are there of them ?

We have taken for study two series of cases of urinary retention due to prostatic enlargement from a single hospital and separated by an interval of eight years. This has two advantages. In the first place some form of treatment was essential for each patient to relieve his retention; the two groups are therefore closely comparable. Secondly, in this investigation we knew exactly how many patients were not chosen for prostatectomy and what happened to them.

The purpose of the investigation was threefold: to obtain full information of the number and type of cases needing treatment for prostatic obstruction, to contrast the causes of death in the two series, and to find out the effects of retention on prostatectomy mortality.
The Survey

Two samples of 200 patients each were chosen, the first from April, 1949, to December, 1952 (series A), and the second from December, 1957, to May, 1960 (series B). Each was a consecutive series of patiente with urinary retention due to prostatic enlargement coming under the care of a surgical team who accepted all such cases admitted to hospital.

All men in each group were under the personal cart of one of us, and the two periods were chosen because they were the earliest and the latest during which sucb personal supervision was undertaken and accurate records were kept.

"Mortality" is given a wide reference. It is taken to mean death of the patient from whatever cause while still under hospital care even after treatment of his prostatic obstruction had been successfully concluded. It has no arbitrary time limit.

The types of prostatic obstruction covered by the two series are adenoma, carcinoma, and chronic inflammatory disease, with or without calculus formation. Acute prostatitis is not included. The obstruction was such as to cause urinary retention and to necessitate relief by some form of bladder drainage. By retention is meant a bladder palpably distended on simple abdominal examination; we have not included those who clinically or radiologically merely had a high residual urine after micturition. Cases of transient retention of nervous or postural origin after surgical operations have been eliminated, as have those who after a single catheterizetion regained normal micturition.

TABle I.-Causes of Urinary Retention in Series A and Series B

\begin{tabular}{|c|c|c|c|c|c|c|c|c|}
\hline & \multicolumn{2}{|c|}{$\begin{array}{l}\text { Pibro- } \\
\text { adenoma }\end{array}$} & \multicolumn{2}{|c|}{ Carcinoma } & \multicolumn{2}{|c|}{$\begin{array}{l}\text { Fibrous/ } \\
\text { Calculous }\end{array}$} & \multicolumn{2}{|c|}{ Total } \\
\hline & $\mathbf{A}$ & B & $\mathbf{A}$ & B & $\mathbf{A}$ & B & $\mathbf{A}$ & $\mathbf{B}$ \\
\hline $\begin{array}{l}\text { Prostatectomy .. } \\
\text { No operation .. }\end{array}$ & $\begin{array}{r}107 \\
55\end{array}$ & $\begin{array}{r}109 \\
50\end{array}$ & $\begin{array}{l}19 \\
10\end{array}$ & $\begin{array}{l}13 \\
22\end{array}$ & $\begin{array}{l}3 \\
6\end{array}$ & $\underline{6}$ & $\begin{array}{r}129 \\
71\end{array}$ & $\begin{array}{r}128 \\
72\end{array}$ \\
\hline Total & 162 & 159 & 29 & 35 & 9 & 6 & 200 & 200 \\
\hline
\end{tabular}

